DOI: 10.17951/lrp. 2018.37.1.11-21

\title{
STANISŁAWA WŁOCH
}

Uniwersytet Opolski

\section{PEDAGOGIKA TRANSGRESYJNA W WYCHOWANIU PRZEDSZKOLNYM}

\begin{abstract}
Streszczenie: Wiek XXI cechuje się przyśpieszonym tempem życia, zachodzącymi zmianami cywilizacyjnymi, kulturalnymi i technologicznymi, dlatego wymaga innego spojrzenia na człowieka przyszłości. Decydującą rolę w tym zakresie odgrywa edukacja od przedszkola do dorosłości. Współczesna pedagogika przedszkolna poszukuje innowacyjnych rozwiązań w zakresie wyzwalania potencjału genetycznego i rozwoju wielowymiarowej osobowości. Jedną z koncepcji stanowi pedagogika transgresyjna, która polega na przekraczaniu własnych możliwości przez działanie, doświadczanie, samodzielność i odpowiedzialność. W artykule ukazano podstawy teoretyczne transgresji, czynniki wyzwalające możliwości dziecka, organizację pola edukacyjnego oraz procesu rozwoju wynikającego z transgresji.
\end{abstract}

Słowa kluczowe: transgresja, pedagogika transgresyjna, rozwój, edukacja

\section{WPROWADZENIE}

Radykalne i szybkie zmiany zachodzące w świecie wymagają nowego spojrzenia na rozwój jednostki. Wiek XXI cechuje się dynamiką nieustannych wydarzeń i przyspieszonego tempa życia. Zmiana to po prostu ruch, który wyznacza modyfikacje w przygotowaniu jednostki do życia na miarę nowych warunków zaistniałych w kulturze, gospodarce, polityce, technice i innych dziedzinach życia społecznego. Zmiana następuje wtedy, gdy jednostka ją wdrażająca dokonuje przemian we własnym rozwoju, pokonuje trudności i problemy oraz angażuje się w nowe wyzwania.

W przystosowaniu się jednostki do zmian decydująca rolę odgrywa edukacja. Tradycyjne uczenie oparte na teorii behawioralnej i ważności zadań programowych nie ma już miejsca we współczesnym świecie. Potrzebą naszych czasów jest uczenie innowacyjne i antycypacja zmian, nabywanie umiejętności uczenia się 
i rozwijanie kreatywności przez wyzwalanie cechy transgresji. Dawniej jednostka była podporządkowana regułom wykonywania prac według określonych zasad, co nie wpływało na rozwój transgresji. Człowiek od najmłodszych lat odbierał polecenia „Tak nie rób!”, „Tak nie wolno!”, trzeba pracować i posłusznie wykonywać polecenia. Jednostka w obecnych czasach to osoba, która myśli, działa, jest kreatywna i ma możliwości podejmowania decyzji i własnego wyboru. Człowiek wychowany w posłuszeństwie opartym na realizowaniu tego, co życzy sobie rodzic, nauczyciel, pracodawca w życiu dorosłym nie osiągnie sukcesu. Surowe reguły hamują rozwój transgresji niezbędnej u człowieka we współczesnym świecie (Juul 2014). Współczesna edukacja wymaga zmian w zakresie modelu kształcenia i wychowania, podejścia do pytań: „Kim dziecko jest?”, „Kim może się stać?, „Jakie są jego możliwości?”, bowiem „człowiek nie jest kimś od razu, ale raczej kimś, kto dopiero ma stać się tym, kim z natury być może" (Kozielecki 1995, s. 98). A może stać się jednostką twórczą i kreatywną wtedy, kiedy proces wychowania od najmłodszych lat będzie polegał na rozbudzaniu ciekawości świata, umożliwianiu eksperymentowania, badania i wchodzenia w interakcje $\mathrm{z}$ otoczeniem społecznym i kulturowym. W wychowaniu dzieci w wieku przedszkolnym nie tylko w krajach postkomunistycznych, ale również wysoko rozwiniętych ciągle poszukuje się innowacyjnych rozwiązań, które zdeterminowane są przez zachodzące procesy cywilizacyjne. Dziecko nie jest biernym odbiorcą informacji, wiedzy, nabywania kompetencji, lecz osobą aktywną, która kształtuje siebie przez podejmowane działania. Dziecko przystosowuje się do otaczającego świata przez naturalny rozwój, który Edelstein określa „jako naturalne uczenie się, wyzwalanie i rozwijanie wewnętrznych predyspozycji, zdobywanie wiedzy i doświadczeń zgodnych z jego naturalnym rozwojem" (Edelstein 1992, s. 161-172). Spróbujmy odpowiedzieć na podstawowe pytanie problemowe: $\mathrm{w}$ jakim zakresie pedagogika transgresyjna ma miejsce $\mathrm{w}$ procesie wychowania i kształcenia dzieci w wieku przedszkolnym?

\section{PODSTAWY TEORETYCZNE TRANSGRESJI}

Transgresja (z łac. transgressio - przejście) - dziedziczenie uwarunkowane, przekroczenie cech organizmów rodzicielskich przez mieszanie, tzn. silniejszy rozwój danej cechy u mieszańców niż u form rodzicielskich (Tokarski 1980, s. 770). Pojęcie to do nauk społecznych (psychologii) w Polsce wprowadził Józef Kozielecki. Zdaniem tego autora transgresja polega na możliwości rozszerzania własnej działalności oraz na przekraczaniu różnego typu barier i granic, dążeniu do zmiany samego siebie i świata. 
Działania, które polegają na tym, że człowiek świadomie przekracza dotychczasowe granice materialne, społeczne i symboliczne są działaniami transgresyjnymi. Wychodzenie poza granice i przekraczanie możliwości jest źródłem rozwoju nie tylko własnego „ja”, lecz także otoczenia i świata. Transgresja zawsze nastawiona jest na zmianę siebie i otoczenia (Kozielecki 1987).

Abraham Maslow uważał, że przekraczanie granic swoich możliwości jest ważną i wrodzoną cechą natury ludzkiej, człowiek przekracza bowiem siebie, aby być sobą, aby lepiej spełniać się w życiu, aby zaspakajać własne potrzeby egzystencjalne. Naczelnym interesem człowieka jest jego rozwój i samoświadomość rozwoju, siłą napędową zaś potrzeba samoaktualizacji (Maslow 1986, s. 63). Rollo May podkreśla, że to, czy potencjalność stanie się aktualnością, zależy w pewnym stopniu od jednostki, która doświadcza, działa, tworzy i realizuje własne potrzeby i cele. „Ciąg ludzkiego doświadczenia można ująć, pojmując-mogę-chcę-jestem” (May 1995, s. 95-102). Ja mogę, ja chcę, ja dążę - są podstawowymi składnikami osobowości transgresyjnej.

Psychotransgresjonizm ujmuje jednostkę jako byt sprawczy, jako obdarzoną wolnością wyboru, samodzielnością działania i decydowania o własnym rozwoju. Kozielecki wyróżnia dwa rodzaje działań: działania ochronne i transgresyjne. Działania ochronne (zachowawcze) służą przetrwaniu i są nastawione na wykonywanie wszelkiego rodzaju czynności rutynowych, odtwórczych, reproduktywnych, codziennych, które umożliwiają przystosowanie się do otoczenia, nie pozwalają natomiast na przekształcenie rzeczywistości, na burzenie starych nawyków, na wyzwalanie potencjału twórczego, rozwój zdolności, nowych struktur społecznych czy cywilizacyjnych. Działania transgresyjne służą rozwojowi nie tylko siebie, lecz także społeczeństwa, są ukierunkowane na wyniki, które przekraczają dotychczasowe osiągnięcia w różnych dziedzinach życia, pozwalają na zmianę rzeczywistości (Kozielecki 2002). Szczególną uwagę zwraca się na transgresje ekspansywne, twórcze, które umożliwiają rozwój osobowości kreatywnej, a nie zachowawczej.

Czynności transgresyjne są głównie regulowane przez potrzeby wewnętrzne: samoświadomość, zainteresowania i zdolności, które dana osoba realizuje przez działania. Człowiek odsłania się w działaniu i przez to działanie się spełnia (zob. Włoch 2003).

Rozwój jednostki polega na utrwalaniu się progresywnej równowagi między nią a światem przez stopniowe włączanie się do świata, a zwłaszcza do świata społecznego, za pomocą aktywnego i twórczego działania, przez które staje się aktywnym podmiotem samodzielnie regulującym własny rozwój, za który ponosi własną odpowiedzialność (Zaborowski 2002, s. 220). 
Człowiek jest sprawcą nastawionym na rozwój wewnętrzny i zewnętrzny, lecz ma ograniczoną świadomość i samoświadomość, która odgrywa istotną rolę w kształtowaniu osobowości transgresyjnej. Działania i czynności transgresyjne mają podłoże w samoświadomości jednostki żyjącej w określonym środowisku, które dostarcza jej różnorodnych treści, wzbogacając wiedzę w zakresie poznania siebie i otaczającego świata. Samoświadomość pozwala na orientację w swoich możliwościach (silnych i słabych stronach) oraz krytyczną analizę własnych zachowań. Pozwala także na wgląd we własny wewnętrzny świat i problemy w relacjach do siebie samego, co może wpływać na wyzwalanie potencjału twórczego i możliwości działania przekraczającego granice rozwoju. Człowiek koduje i przetwarza różnego typu informacje o sobie samym, o relacjach ze światem, co pozwala mu na zrozumienie świata i samego siebie (Łukaszewski 1998). W transgresji Kozielecki wyróżnia dwa typy działań: „wiem, że muszę” oraz „wiem, że mogę”. Pierwszy typ działań wiąże się z czynnościami adaptacyjnymi, ochronnymi, które są niezbędne w życiu jednostki, aczkolwiek nie wnoszą żadnych zmian czy nowych elementów. Są to działania typu odtwórczego i przystosowawczego, które w niskim zakresie mają wpływ na rozwój myślenia aktywnego, twórczego, perspektywicznego oraz odkrywania i przeżywania własnych doznań. Działania typu „wiem, że mogę”, „potrafię samodzielnie”, „wykonam i chętnie podejmuję” prowadzą do przekraczania możliwości wykonywania zadań, przekształceń, rozwiązań i zmieniają świat oraz człowieka.

Wydaje się, że transgresja w świecie, w którym poszukuje się nowoczesnych systemów i rozwiązań edukacyjnych w zakresie rozwoju człowieka o pełnej, konstruktywnej i biofilicznej (From 1998) osobowości staje się podstawą i siłą w tworzeniu nowych warunków i zadań procesu kształcenia i wychowania od najmłodszych lat.

\section{PEDAGOGIKA TRANSGRESYJNA W EDUKACJI PRZEDSZKOLNEJ}

W okresie dzieciństwa stajemy się aktywnymi odbiorcami świata i przez ten świat kształtujemy siebie. Proces uczenia się i rozwoju jest złożony i wiąże się z wieloma czynnikami, które stymulują rozwój osobowości. Wczesna edukacja pozwala na ukazywanie dziecku jego własnej egzystencji i życia ludzi w danym środowisku, przybliżenie pojęcia świata. To okres, w którym dzieci stopniowo nabywają umiejętności oceniania i porządkowania cech rzeczy, ludzi i zjawisk. W okresie wieku przedszkolnego dziecko przejawia niezwykłą dynamikę w poznawaniu świata i zachodzących w nim relacji. Ciekawość, chęć poznania, doświadczanie rzeczywistości oraz samodzielnego działania to nic innego jak dążenie do poznania siebie, 
otoczenia, wartości i wzorów zachowań oraz wyzwalania własnego potencjału genetycznego i ukrytych możliwości ${ }^{1}$. Glenn Doman twierdzi, że nigdy w historii ludzkości nie było dorosłego naukowca, który miałby połowę tej ciekawości, jaką wykazuje dziecko między 18 miesiącem a 5 rokiem życia (Doman 1992, s. 39-40).

Dzieciństwo jest podstawowym etapem dla każdego następnego okresu życia, stanowi kategorię społeczno-kulturową i oznacza nie tylko etap w życiu każdego człowieka, określoną fazę rozwoju, ale obecnie rozumiane jest jako świat dziecka, świat jego przeżyć, doświadczeń, aktywności i relacji, jakie w tym wieku zachodzą ze światem zewnętrznym (Matyjas 2008, s. 36). Dziecko w wieku przedszkolnym to osoba ucząca się, która dostrzega zjawiska nieznane i odległe, pokonuje trudności i rozwiązuje problemy, przeżywa i przekracza własne możliwości - stopniowo staje się jednostką transgresyjną i twórczą. Postawmy więc pytanie: dlaczego dzieci, skoro ich umysły i potencjał rozwojowy są tak fantastycznie zaprojektowane do uczenia się i przekraczania własnych możliwości, po przekroczeniu progu szkolnego często przestają się sprawdzać i są zniechęcone do nauki?

Współczesna szkoła (a czasami również przedszkole) nie rozwija i nie uczy po dziecięcemu. Jest wykorzystana przez dorosłych, których mózgi już dawno zapomniały dzieciństwo. To właściwie dorośli wymyślają programy, podręczniki, metody, organizują zajęcia, nie znając rozwoju umysłu dziecka i jego możliwości. Dzieciom serwujemy suche fakty, wykorzystujemy metody podające, pozbawiamy przyjemności samodzielnego poznawania świata i rozwoju potencjału myślowego. Nadal współczesna edukacja opiera się na założeniach edukacji urabiającej i rozliczającej nauczyciela. Wycinkowe badania wykazały, że współczesnego nauczyciela nie rozlicza się z efektywności rozwoju dziecka, lecz z godzin realizowanego programu $^{2}$. Dziecko odkrywa, samodzielnie rozwiązuje problemy, nabywa zrozumiałą wiedzę, ujawnia cechy transgresji, a to wszystko pomaga mu w znalezieniu ciągłości i powiązań w jego życiu na dalszych etapach rozwoju. Transgresja pozwala mu zrozumieć zjawiska zachodzące w świecie, dokonywać wyboru własnych wartości oraz nabywać umiejętności reagowania na postawy jednostek i społeczeństwa. Pedagogika transgresyjna w edukacji dzieci opiera się na teorii rozwojowej, która uwzględnia świadome dążenie ku rozwijaniu specyficznych wartości, norm, umiejętności pokonywania trudności i przekraczania własnych możliwości w działaniu.

Kształcenie transgresyjne wymaga określenia niezbędnych czynników sprzyjających przekraczaniu własnych możliwości:

${ }^{1}$ Wykorzystano artykuł S. Włoch opublikowany w książce Pedagogika kreatywna wyzwaniem edukacji XXI wieku, Opole 2010.

2 Wycinkowe badania wśród studentów studiów niestacjonarnych pracujących w szkole i przedszkolu. 
- Organizowanie pola edukacyjnego, czyli miejsca i przestrzeni oraz bazy dydaktycznej. Dziecko rozwija się wtedy, kiedy podejmuje różnorodne działania, doświadcza pewnych stanów wewnętrznych, przekraczając nieraz własne możliwości. Rozwój zależy od tego, czy dziecko ma zapewnioną przestrzeń, środki dydaktyczne i miejsce do własnej działalności. Pole edukacyjne stwarza jednostce możliwości podejmowania aktywności i samorealizacji, pozwala na samodzielność i dążenie do określonego celu. Każde dziecko rozwija się w odpowiednim miejscu i przestrzeni, które emanują życiem i kształtują osobowość przyszłego człowieka. Przestrzeń bywa rozumiana jako zespół zachowań ludzkich, materialna i niematerialna część otoczenia, środowisko, budowle, przedmioty (Nalaskowski 2002, s. 23). Przedszkole jako przestrzeń edukacyjna składa się z wielu warstw, wielu miejsc, kształtów i wyobrażeń (tamże, s. 81). Dziecko zostaje umiejscowione w określonej przestrzeni i pomieszczeniu, a organizacja miejsca to warunek tworzenia podmiotowości. Przestrzeń i miejsce określają, jak dzieci mogą być postrzegane i oceniane. W przestrzeni edukacyjnej dziecko ma możliwości podejmowania czynności rozwijania własnego potencjału oraz ukazania siebie jako pełne inicjatywy zaangażowania i możliwości rozwojowych. W przestrzeni niezapewniającej samodzielności i aktywności może być postrzegane jako osoba pasywna, rozkojarzona, o negatywnych postawach. Zachowania i aktywność dziecka uwarunkowane są miejscem i sytuacją, w których się ono znajduje (Nordin-Hultman 2004, s. 170). Środowisko lokalne przyczynia się do rozwoju transgresji, bowiem polega ono na integracji między dzieckiem a środowiskiem. Przez kontakt dziecka ze środowiskiem przyrodniczym, społecznym i kulturowym, przez uczestniczenie $\mathrm{w}$ działaniu w danym środowisku umysł, uczucia i zachowania wyzwalają potencjał twórczego działania i przekraczania własnych możliwości. Przykładem może być edukacja skandynawska, w ramach której dzieci mają możliwości budowania szałasów, wykonywania różnego rodzaju eksperymentów, poszukiwania samodzielnych rozwiązań, zjawisk przyrodniczych, społecznych i technicznych w formie różnego rodzaju zabaw. Tego rodzaju działania pozwalają dzieciom na rozwijanie cech transgresyjnych ${ }^{3}$;

- Rozwój transgresji u dzieci polega na doświadczaniu czegoś, co wywołuje coś szczególnego. Stwarzanie możliwości i zrozumienie doświadczeń dziecka wymaga skupienia uwagi na rzeczach, które zajmują i interesują dziecko w jego dziecięcym świecie. Każda sytuacja dla niego staje się polem doświad-

${ }^{3}$ Autorskie przykłady organizowania pola edukacyjnego w środowisku. Utomhuspedagogik i förskola och forskoleklass, 2008, Tidningen Förskolans redaktion. 
czeń, które pozostawia ślad w jego świadomości (Johansson, Samuelsson 2003). Dziecko rozwija się w działaniu i przez działanie, w którym kreuje siebie, doświadcza, staje się aktywne i autonomiczne, dokonuje wyboru, preferuje, urzeczywistnia własne umiejętności i możliwości oraz dąży do transgresji. Cechuje się również wewnętrznym stanem świadomości, który pobudza go do podejmowania czynności i rozwijania własnej samodzielności i aktywności, do wyzwalania ukrytego potencjału twórczości. Jest to właściwość wiążąca się z zewnętrznym zachowaniem dziecka i konceptualizowaniem jako „bycie zajętym” (Włoch 2005, s. 53-59). Ten wewnętrzny aspekt „bycia zajętym” stanowi wyzwalanie w dziecku tzw. gotowości do czynienia „czegoś”, ale tylko wtedy, gdy ma warunki do działania, badania i eksperymentowania. Działania prowadzą do zdobywania doświadczeń, które tworzą świadomość dziecka i mają wpływ na rozwój procesów intelektualnych i emocjonalnych. Doświadczenia nie tylko przyczyniają się do zastanawiania, interpretowania, zrozumienia związku i relacji zachodzących między przedmiotami czy zjawiskami, ale przede wszystkim są stymulatorami rozwoju postawy transgresyjnej. Roland Maighan proponuje uznanie prawa dziecka do jego własnego rozwoju, jego własnej edukacji, w której ma możliwość rozwijania i przekraczania siebie przez samodzielnie podejmowane działania badawcze, projektowe, poszukiwawcze czy odkrywcze. Oznacza to, że proces stymulowania transgresji polega na organizowaniu sytuacji dostosowanych do możliwości dziecka, które przyczyniają się do ich przekraczania, aby mogło doświadczać naturalnych zjawisk z otaczającej rzeczywistości oraz wyrażać własne, myśli, emocje, przeżycia i radość z wykonywanego działania. Edukacja transgresyjna to proces skierowany ku dziecku, jego procesom myślowym i emocjonalnym oraz jego potrzebom rozwojowym.

Edukacja ma znaczenie w rozwoju cech kreatywnych i transgresyjnych wtedy, gdy dziecko jest traktowane jako niepowtarzalna indywidualność $\mathrm{z}$ jego osobistymi doświadczeniami, zainteresowaniami, ciekawością poznawczą i emocjonalną (Denek 1998, s. 91). W koncepcji kształcenia transgresyjnego istotną rolę odgrywają metody i formy stymulujące dziecko do podejmowania różnego rodzaju czynności. Każdy akt poznania albo sam jest aktem działania, albo też jest przyporządkowany działaniu. Umysł przetwarza te informacje, które sam pobrał z otoczenia w wyniku wykonywanych czynności, oraz te, które są mu potrzebne (Nęcka i in. 2006, s. 29-30). Poznanie nie istnieje bez działania.

Rozwój dziecka jest uzależniony od możliwości działania i jego twórczej aktywności. Działanie z własnych pobudek i potrzeb daje dziecku możliwość kontroli i panowania, 
w związku z tym wymaga się, by dzieci miały dostęp do działania, które wyzwala aktywność, zaangażowanie i kreatywność (Lövle 1982, s. 5).

Pedagogika transgresyjna kładzie szczególny nacisk na podejście sytuacyjne w przeciwieństwie do podejścia nakazowego, zadaniowego czy biernego, które polega na organizowaniu sytuacji, w których coś się dzieje, które zaskakują dzieci, w których trzeba wykonać szereg czynności, zdobyć się na wysiłek myślowy i działaniowy. Znalezienie się dziecka w takiej sytuacji wytwarza swoiste oczekiwania, zainteresowania, motywację do wysiłku wyzwalającego własne możliwości i ich przekraczanie. Dziecko przestaje być jedynie obiektem działań wychowawczych, a staje się przedmiotem własnego działania, ma możliwości uczenia się przez odkrywanie, stawianie pytań, przypuszczeń, samodzielne działanie i rozwiązywanie przejawiające się w różnorodnych czynnościach.

Przekraczanie własnych możliwości następuje wtedy, kiedy nauczyciel ogranicza metody podające, oparte na aktywności nauczyciela na rzecz metod aktywizujących opartych na:

- działaniu praktycznym - prace społeczne, prace w instytucjach i środowisku przyrodniczym, naśladowanie czynności dorosłych, wykonywanie upominków, modeli urządzeń, przeprowadzanie doświadczeń, badań, wyzwalanie ekspresji plastycznej, technicznej, słownej;

- odkrywaniu - rozwiązywanie problemów i zadań, pytań alternatywnych w bezpośrednim kontakcie ze środowiskiem, poszukiwanie związków wiedzy w autentycznym życiu środowiska;

- $\quad$ obserwacji uczestniczącej - pokaz przedmiotów, zjawisk w naturalnym środowisku społecznym i przyrodniczym;

- przeżywaniu - zaciekawienie, zdziwienie, zainteresowanie, wyzwalanie uczuć i właściwych postaw wobec otoczenia, wpajanie wartości.

Analiza badań przeprowadzonych przez studentów wśród nauczycieli wykazała niski stopień wykorzystania następujących metod w procesie wychowania dzieci w wieku przedszkolnym: metody problemowej, projektu, symulacyjnej, dialogu, opowiadań twórczych. A przecież wiadomo, że te rodzaje metod rozwijają samodzielność, myślenie, twórczość i cechy transgresyjne. Badani nauczyciele nadal korzystają z metod opracowanych w latach 70. i 80. Metody oparte na działaniu i aktywności prowadzą do rozwoju dziecka, które staje się sprawcą transgresyjnym, potrafi „przesuwać” granice własnych osiągnięć, przekracza siebie i staje się jednostką kreatywną i odpowiedzialną. Proces wychowania w przedszkolu opiera się zatem na stwarzaniu szans przeżywania, doświadczania, poznawania, spotykania i potwierdzania własnych możliwości. Proces wychowania w przedszkolu jest ekscytujący i urozmaicony - dzieci mogą dowiedzieć się czegoś o własnych zdolnościach, 
wypróbować i poznawać siebie, eksplorować własne wewnętrzne „ja”. W kształceniu transgresyjnym ogromną rolę odgrywa atmosfera wychowania i postawa nauczyciela.

Przedszkole rozwijające postawy transgresyjne staje się miejscem uczenia się, myślenia i poznania siebie i świata, miejscem, w którym panuje atmosfera życzliwości, akceptacji, wzmacniania indywidualności, odpowiedzialności, otwartości i zaskoczenia. Działania oparte na własnych możliwościach i umiejętność ich przekraczania zgodnie z naturalnym rozwojem dziecka prowadzą do rozwoju jednostki, która w przyszłości potrafi przystosować się do zmian, rzadziej będzie doznawała uczucia frustracji i lęku, a przyszłość stanie się dla niej „szansą, a nie ścianą płaczu”.

Pedagogika transgresyjna zwraca również szczególną uwagę na przygotowanie nauczycieli do pracy $\mathrm{z}$ dziećmi $\mathrm{w}$ wieku przedszkolnym. Badania przeprowadzone wśród nauczycieli wychowania przedszkolnego wykazały, że w edukacji studentów na kierunkach nauczycielskich zabrakło elementów wyzwalających ich potencjał twórczy, jak i elementów rozwijających osobowość kreatywną i transgresyjną. Kształcenie nauczycieli opiera się wyłącznie na przeteoretyzowaniu przekazanych treści i to nieraz zdezaktualizowanych i mało przydatnych w praktyce szkolnej. Szkoły wyższe w małym stopniu przywiązują wagę do wszechstronnego wykształcenia ogólnego, w szczególności w zakresie kultury osobistej, samorozwoju, transgresji, rozwiązywania problemów pedagogicznych, pokonywania trudności, a nawet radzenia sobie $\mathrm{z}$ osobistym problemami.

Najwięcej kontrowersji budzi przygotowanie praktyczno-pedagogiczne i własny rozwój osobowości, które nie spełniają oczekiwań studenta i zawierają wiele niedoskonałości. Treści z przedmiotów pedagogicznych i psychologicznych są bardzo przeładowane teorią, nie pokazują związku naturalnego rozwoju z procesami edukacyjnymi. Całokształt kształcenia opiera się na pedagogice teoretycznej, która nie uwzględnia bezpośredniego udziału studenta w tworzeniu, rozwijaniu kreatywności i działaniu, angażującymi nie tylko procesy intelektualne, ale i emocjonalne. W kształceniu zabrakło miejsca na twórczość, działanie pedagogiczne oparte na przeżyciach i doznaniach wewnętrznych. Jedna z badanych absolwentek stwierdziła, że ze studiów pamięta tylko wykładowców stojących przed katedrą z mikrofonem w ręce, laptopem, którzy pozbawiali przeżywania i odczuwania samej siebie $\mathrm{w}$ dusznym i zatłoczonym pomieszczeniu. A przecież $\mathrm{w}$ kształtowaniu młodego człowieka liczy się nie tyle naśladownictwo, co realizacja impulsów, indywidualna inicjatywa jako wyważona równowaga w działaniu.

Wobec rosnących wymagań społecznych w kształceniu nauczycieli nie może zabraknąć podstaw „uczenia się zmiany oraz uczenia się ewaluacji - ku nauczaniu żywemu”. Nie są w stanie podołać temu studenci, którzy ograniczają się do wkuwania i przyswajania gotowej wiedzy (Grzesiak 2007, s. 43). 


\section{PODSUMOWANIE}

Kształcenie transgresyjne jest procesem złożonym, wymagającym zarówno wiedzy, doświadczeń, jak i pogłębionych badań empirycznych. Pedagogika oparta na przekraczaniu możliwości rozwojowych dziecka wskazuje na jej oryginalność, która przyczyniać się będzie w życiu dorosłym do przekształcania własnej osoby i świata. Zgodnie z założeniami kształcenia transgresyjnego nie należy uczyć wszystkiego, należy uczyć jedynie tego, co jest ważne w procesie perspektywicznego przystosowania się do nowych warunków życia i przejawiania twórczości i transgresji w życiu dorosłym. Pozostaje to w zgodzie ze wskazaniami Jeroma S. Brunera, że „aby coś przyswoić, trzeba wiedzieć, co to ma być i samodzielnie to odkryć" (Bruner 1989, s. 142), bo tylko ta droga zdobywania wiedzy i umiejętności prowadzi do akceptacji, fascynacji i wykorzystania jej w życiu. Tak pojęta edukacja nie staje się transmisją treści, lecz edukacją wspierającą indywidualny rozwój oparty na samodzielnych i twórczych doświadczeniach i różnorodnych działaniach dziecka wspomagających proces wychowania przedszkolnego.

\section{LITERATURA}

Bruner J.S., 1989, Poza dostarczone informacje. Warszawa, Wydawnictwo PWN.

Denek K., 1998, O nowy kształt edukacji. Toruń, Wydawnictwo Edukacyjne Akapit. Doman G., 1992, Jak nauczyć małe dziecko czytać - cicha rewolucja. Bydgoszcz, Wydawnictwo Excalibur.

Edelstein W., 1992, Development as the Aim of Education - Revisitet in Effective and Responsible Teaching. San Francisco, Jossey-Bass Publishers.

From E., 1998, Anatomia ludzkiej destrukcyjności. Poznań, Wydawnictwo Rebis.

Grzesiak J., 2007, Ewaluacja i innowacje w edukacji nauczyciela - w kontekście pedagogiki szkoły wyższej. W: J. Grzesiak (red.), Ewaluacja i innowacje w edukacji nauczyciela. Konin, Państwowa Wyższa Szkoła Zawodowa w Koninie.

Johansson E., Samuelsson I.P. (red.), 2003, Förskolan - barns första skola. Lund.

Juul J., 2014, Kryzys szkoły. Co można zrobić dla uczniów, nauczycieli i rodziców. Podkowa Leśna, Wydawnictwo MIND.

Kozielecki J., 1996, Człowiek wielowymiarowy. Warszawa, Wydawnictwo Żak. Kozielecki J., 1995, Koniec wieku nieodpowiedzialności. Warszawa, Jacek Santorski \& Co, Agencja Wydawnicza.

Kozielecki J., 1987, Koncepcja transgresyjna człowieka. Warszawa, Wydawnictwo PWN. Kozielecki J., 2002, Psychologia czynności. Warszawa, Wydawnictwo Naukowe Scholar. Kozielecki J., 1997, Transgresja i kultura. Warszawa, Wydawnictwo Żak. 
Lövle A.L., 1982, The Self: Yours, Mine or Ours: a dialectical viev. Oslo, Aschehoug AS. Łukaszewski W., 1998, Czynniki decydujace o powodzeniu wychowania. W: B. Smoczyńska (red.), Studia z psychologii rozwojowej i psycholingwistyki. Kraków, Towarzystwo Autorów i Prac Naukowych Universitas.

Maslow A., 1986, W strone psychologii istnienia, przeł. I. Wyrzykowska. Warszawa, Wydawnictwo PAX.

Matyjas B., 2008, Dzieciństwo w kryzysie, etiologia zjawiska. Warszawa, Wydawnictwo Żak, Teresa i Józef Śniecińscy.

May R., 1995, O istocie człowieka, przeł. M. Moryń, Z. Wiese. Poznań, Dom Wydawniczy Rebis.

Nalaskowski A., 2002, Przestrzenie i miejsca szkoły. Kraków, Wydawnictwo Impuls. Nęcka E., Orzechowski J., Szymura B., 2006, Psychologia poznawcza. Warszawa, Wydawnictwo PWN, Academica Wydawnictwo SWPS.

Nordin-Hultman E., 2004, Pedagogiska miljöer och barns subjektsskapande. Stockholm. Tokarski J. (red.), 1980, Słownik wyrazów obcych. Warszawa, Wydawnictwo PWN.

Utomhuspedagogik i förskola och forskoleklass, 2008, Tidningen Förskolans redaktion. Włoch S., 2003, Kształcenie transgresyjne wyzwaniem edukacji XXI wieku. W: K. Denek, T. Koszczyc, M. Lewandowski (red.), Edukacja jutra. Wrocław, Wydawnictwo Wrocławskiego Towarzystwa Naukowego.

Włoch S., 2005, Pedagogika widzialna i niewidzialna w edukacji przedszkolnej, aspekty rozwojowe. W: S. Guz (red.), Rozwój i edukacja dziecka. Szanse i zagrożenia. Lublin, Wydawnictwo Uniwersytetu Marii Curie-Skłodowskiej.

Zaborowski Z., 2002, Człowiek, jego świat i życie. Warszawa, Wydawnictwo Żak.

\title{
PEDAGOGY OF TRANSGRESSION IN PRESCHOOL EDUCATION
}

\begin{abstract}
The $21^{\text {st }}$ century is characterized by the accelerating pace of life as well as civilization, cultural and technological changes. Therefore, it requires a new view on the future human being. Education from preschool to adulthood plays a crucial role in this regard. Contemporary preschool pedagogy is searching for innovative solutions in the field of unleashing genetic potential and development of the multidimensional personality. One of the new ideas is pedagogy of transgression, consisting in exceeding one's own limitations through activity, experience, self-reliance and responsibility. The paper shows theoretical foundations of transgression, factors which unleash child's capabilities, organization of the educational field as well as organization of the process of transgression-based development.
\end{abstract}

Keywords: transgression, pedagogy of transgression, development, education 